\title{
FLIGHT TESTS OF TURBOPROP ENGINE WITH REVERSE AIR INTAKE SYSTEM
}

\author{
Marek Idzikowski, Wojciech Miksa \\ Instytut Lotnictwa, Centrum Nowych Technologii \\ Al. Krakowska 110/114, 02-256 Warsaw, Poland \\ wojciech.miksa@ilot.edu.pl
}

\section{Abstract}

This work presents selected results of I-31T propulsion flight tests, obtained in the framework of ESPOSA (Efficient Systems and Propulsion for Small Aircraft) project. I-31T test platform was equipped with TP100, a $180 \mathrm{~kW}$ turboprop engine. Engine installation design include reverse flow inlet and separator, controlled from the cockpit, that limited ingestion of solid particulates during ground operations. The flight tests verified proper air feed to the engine with the separator turned on and off. The carried out investigation of the intake system excluded possibility of hazardous engine operation, such as compressor stall, surge or flameout and potential airflow disturbance causing damaging vibration of the engine body. Finally, we present evaluation of total power losses associated with engine integration with the airframe.

Keywords: light aircraft, flight tests, turboprop engine installation, turboprop engine integration, reverse air flow to engine.
Abbreviations:
$\mathrm{oC}-$ Celsius degree, temperature unit
$\triangle \mathrm{P}$ - power loss
$\triangle T O R Q$ - engine torque loss at shaft
CAS - Calibrated Air Speed
CFD - Computational Fluid Dynamics
$\mathrm{CP}$ - Cruise Power
EGT - Exhaust Gases Temperature
GIP - Ground Idle Power
IAS - Indicated Airspeed
$\mathrm{kW}$ - kilowatts, power unit

$\mathrm{km} / \mathrm{h}$ - kilometers per hour, speed unit

$\mathrm{m}-$ meter, altitude and length unit

$\mathrm{mm} / \mathrm{s}$ - millimeter per second, imbalance unit

$\mathrm{m} / \mathrm{s} 2$ - meters per square meter, acceleration unit

min - minute, time unit

MCP - Maximum Continuous Power

N1 - Gas Generator Rotational Speed

N2 - Propeller Shaft Rotational Speed

OAT - Outside Air Temperature

OFF - separator flap position without flow separation 
$\mathrm{ON}$ - separator flap position for flow separation

PIC - Pilot In Command

PBS - První Brněnská Strojírna Velká Bíteš

$\mathrm{rpm}$ - revolutions per minute, propeller rotation speed unit
TAS - True Air Speed

TOP - Take-Off Power

TORQ - Torque at shaft

VLE - maximum speed with landing gear extended

VS1 - stall velocity with flaps and gear retracted

\section{INTRODUCTION}

I-31T is a light (maximum takeoff mass is $1150 \mathrm{~kg}$ ), all composite, low wing, four-seater airplane with retracted tricycle undercarriage. It is powered by a prototype engine TP100 developed by Czech company První Brněnská Strojírna Velká Bíteš (PBS). At 2158 revolutions per minute (rpm), takeoff shaft power is $180 \mathrm{~kW}$, maximum continuous power is $160 \mathrm{~kW}$, cruise power is $140 \mathrm{~kW}$. Engine control is digital with single power engine control lever (no propeller control lever). TP100 has no air bleeds for airframe needs. German MT-Propeller type MTV-25-1-D-C-F/CFL180-05, is a "constant speed", in-flight controllable-pitch $1.80 \mathrm{~m}$ diameter propeller with feathering and no reverse thrust. It rotates to the left (counter-clockwise in the flight direction). The never extending speed (VNE) and normal operation speed (VNO), are assumed I-31T design limitations. Calibrated airspeed (CAS) values are 332 and $295 \mathrm{~km} / \mathrm{h}$ accordingly [1].

The airplane test program was elaborated and run by Transport Systems Department in New Technologies Center at Instytut Lotnictwa. It included in-flight verification of propulsion operation with European certification requirements CS-23 [2] for normal category airplanes. Pilot-In-Command (PIC) during the flights was first class test pilot with long experience in flying turboprop aircraft.

This work focuses on tests carried out to verify air inlet design and on assessing the impact of propulsion integration with airframe on engine and specifically separator performance.

\section{TP100 ENGINE-AIRFRAME INTEGRATION}

I-31T is based on the piston I-23 design. Nacelle with composite cowlings [3] was designed to incorporate turboprop engine TP100 that replaced old piston 0-360-A1A engine. New engine mount geometry was optimised to minimise its weight [4]. Ground and in-flight test proved sufficient cooling efficiency of the engine compartment [5]. Instytut Lotnictwa elaborated the integration design. Aviation Structures and Design Department did structure design work. Aerodynamic Department did computational fluid dynamics (CFD) analyses of air flow in the inlet duct [6].

Fig. 1 shows the inlet design. Front inlet system consists of the main inlet and two symmetrical side inlets. The main duct provides air for the engine compressor. TP100 design with air intake on the opposite side to the propeller drive shaft forced directing the main duct upwards. Chosen radius is small to reduce total engine compartment length. The left inlet provides the air for cooling oil and engine body. The right inlet provides air for radiator of electric generator - the power source of airplane electric installation, heater and engine body as well. The heater uses the air for heating cockpit. Separator, in the lower part of the duct, protects engine compressor from ingesting foreign objects on the ground. Pilot can control separator flap position through electric actuator. The flap has two positions, it opens the outlet to remove foreign objects. The flap closing the separator has no sealing elements. 


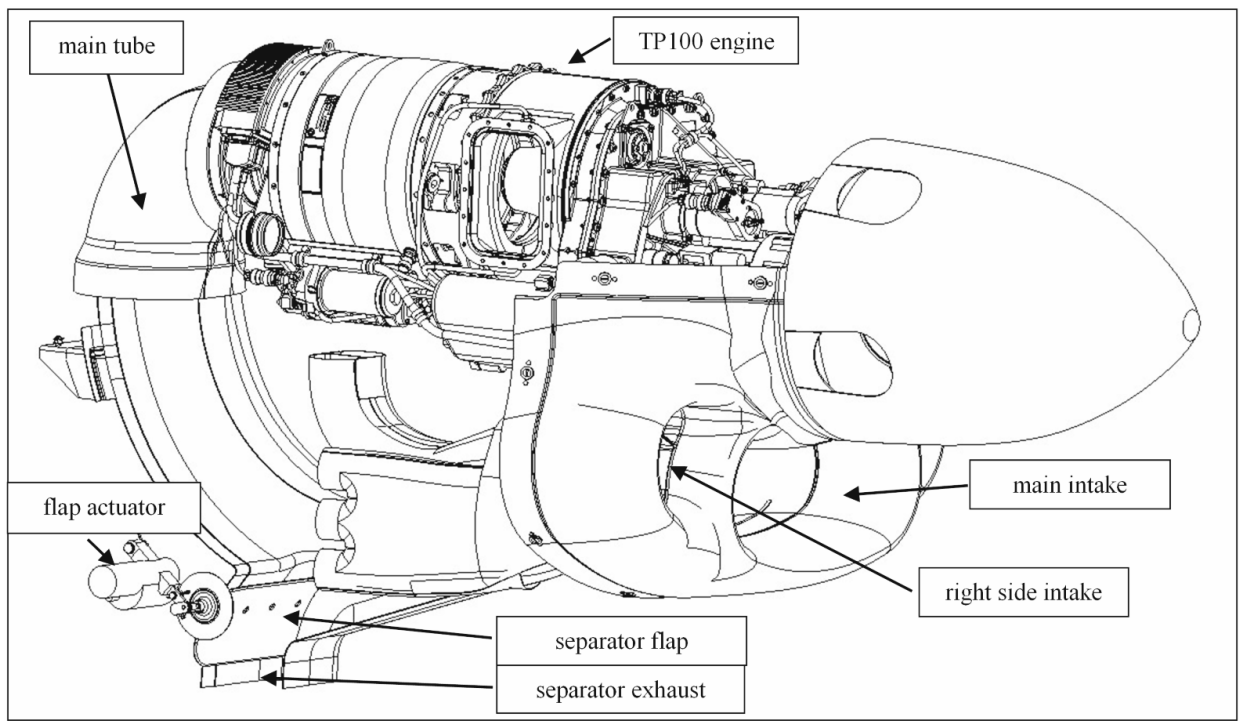

Fig. 1. Cut out view of engine inlet with visible separator flap

\section{AIRCRAFT EQUIPMENT USED DURING THE TESTS}

In order to set initial parameters of a specific flight test task, pilot used onboard pressure instruments (airspeed indicator and altimeter) and INTEGRA engine parameter visualization system screen, shown in Fig. 2.

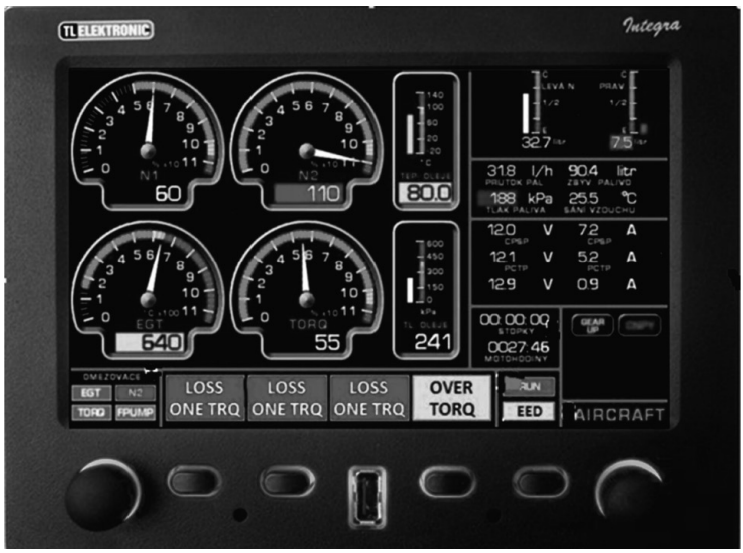

Fig. 2. Front face of TL-6724_PBS INTEGRA engine monitoring system

The INTEGRA system enabled PIC to monitor the engine operation during the tests, displaying analogue and digital values of such parameters as: gas generator rotational speed (N1), propeller shaft rotational speed (N2), exhaust gases temperature (EGT) and shaft torque (TORQ). It can also display up to 4 messages on propulsion malfunctions. Limited number of messages led to implement a procedure of sequencing them depending on their importance. There are three levels defined. Level I 
represents critical malfunctions, that can cause the engine damage, loss of control or shutdown. Level II warns about failures that, while not an immediate threat to the engine, require pilot reaction. Level III consists of failures that do not present a direct threat or engine operation limitations. As example, level I includes: excessive compressor or turbine rotation rate, EGT, or TORQ.

The I-31T airplane is also equipped with a mobile on-board system recording TP100 hull vibrations. The system include two vibration sensors, which location were selected by the engine manufacturer. The first - at front, installed on the engine gearbox records axial up and down vibrations. The second - rear, installed on the hull fitting of the compressor records radial vibrations. Reading of the recorded measurements is possible after the flight.

\section{PROCEDURES AND TEST RESULTS}

\subsection{Evaluation of engine operation during taxiing, take-off, landing and fixed power settings}

The ground test cycle, during which the aircraft was clamped, was followed by over dozen of taxiing tests in windless conditions and then with side and rear directions of wind. Take-off trials included assessing impact of separator settings on the engine operation. The first take-off and maiden flight followed 11 hours of engine operation. During initial flight, the airplane was performing take-offs and landings in calm weather, as well as side winds from both sides. Until investigating unstable engine operation range, flight maneuvers were limited to gentle ones, and the PIC did not move control lever rapidly. Separator was used only during initial phase of take-offs and last stages of landing.

\subsection{Evaluation of unstable range of engine operation}

The crew duty was to monitor all and any issues emerging during engine operation, their kind and conditions and time when they appear. Specific threats to monitor were: compressor stall, irregular $\mathrm{rpm}$, flameout, considerable vibrations [7]. If a test procedure assumed no engine stabilisation after moving power lever, it was carried out as follows: from the specific power lever setting, quick acceleration followed by immediate deceleration to lower rpm than the initial one. Trials were done in the same manner for high and low flight altitude (ca. 3700 and $600 \mathrm{~m}$ ) for clean configuration. Table 1 shows each task parameters.

Table 1. Evaluation of propulsion in flight operation in the unstable range.

\begin{tabular}{|c|c|c|c|c|c|}
\hline \multirow{3}{*}{$\begin{array}{l}\text { Quick power } \\
\text { direction }\end{array}$} & \multirow{3}{*}{$\begin{array}{l}\text { Stabilization after moving } \\
\text { power control lever }\end{array}$} & \multicolumn{4}{|c|}{ Initial IAS [km/h] } \\
\hline & & $\begin{array}{c}\approx 1.1 V_{\mathrm{S} 1} \\
\approx 136 \mathrm{~km} / \mathrm{h}\end{array}$ & $\begin{array}{c}V_{\mathrm{LE}} \\
\approx 180 \mathrm{~km} / \mathrm{h}\end{array}$ & $\approx 240 \mathrm{~km} / \mathrm{h}$ & $\begin{aligned} & \leq V_{\mathrm{NE}} \\
\approx & 300 \mathrm{~km} / \mathrm{h}\end{aligned}$ \\
\hline & & \multicolumn{4}{|c|}{ Impact on engine operation - crew assessment } \\
\hline $\mathrm{GIP} \rightarrow \mathrm{MCP}$ & YES & $\begin{array}{l}\text { No adverse } \\
\text { impact }\end{array}$ & $\begin{array}{c}\text { No adverse } \\
\text { impact }\end{array}$ & $\begin{array}{c}\text { No adverse } \\
\text { impact }\end{array}$ & $\begin{array}{c}\text { No adverse } \\
\text { impact }\end{array}$ \\
\hline $\mathrm{MCP} \rightarrow \mathrm{GIP}$ & YES & $\begin{array}{c}\text { No adverse } \\
\text { impact }\end{array}$ & $\begin{array}{c}\text { No adverse } \\
\text { impact }\end{array}$ & $\begin{array}{c}\text { No adverse } \\
\text { impact }\end{array}$ & $\begin{array}{c}\text { No adverse } \\
\text { impact }\end{array}$ \\
\hline $\begin{array}{l}\mathrm{GIP} \rightarrow \mathrm{CP} \rightarrow \\
\mathrm{GIP}\end{array}$ & NO & $\begin{array}{l}\text { No adverse } \\
\text { impact }\end{array}$ & $\begin{array}{l}\text { No adverse } \\
\text { impact }\end{array}$ & $\begin{array}{l}\text { No adverse } \\
\text { impact }\end{array}$ & $\begin{array}{c}\text { No adverse } \\
\text { impact }\end{array}$ \\
\hline $\begin{array}{l}\mathrm{CP} \rightarrow \mathrm{MCP} \rightarrow \\
\mathrm{CP}\end{array}$ & NO & $\begin{array}{l}\text { No adverse } \\
\text { impact }\end{array}$ & $\begin{array}{c}\text { No adverse } \\
\text { impact }\end{array}$ & $\begin{array}{c}\text { No adverse } \\
\text { impact }\end{array}$ & $\begin{array}{c}\text { No adverse } \\
\text { impact }\end{array}$ \\
\hline
\end{tabular}


In order to evaluate engine operation at low speeds, the tests were done using the landing configuration. Entering and leaving the stall range was done using power lever. Proper engine acceleration was verified through entering climb after long descent at idle power. The crew encountered no problems with the engine at all.

\subsection{Evaluation of engine operation for skewed air inflow to the inlet}

Further step was evaluation of engine in conditions with inclined skewed air flow to the air inlet. Airplane slide angle was the maximum possible one for a given airplane configuration. Tests were carried out in the same way for high and low flight altitudes (between $3700 \div 3000 \mathrm{~m}$ and $600 \mathrm{~m}$ ) for clean and landing configurations. Each task parameters and their results are in the Table 2 . All the tasks were verified positively.

Table 2. Evaluation of engine operation for skewed air inflow to the inlet.

\begin{tabular}{|c|c|c|c|c|c|c|c|c|c|}
\hline \multirow{4}{*}{$\begin{array}{c}\text { Airplane } \\
\text { configuration }\end{array}$} & \multirow{4}{*}{$\begin{array}{c}\text { Power } \downarrow \\
\rightarrow \\
\begin{array}{c}\text { Sideslip } \\
\text { direction }\end{array}\end{array}$} & \multicolumn{8}{|c|}{ Initial IAS [km/h] } \\
\hline & & \multicolumn{2}{|c|}{$\begin{array}{c}\approx 1.1 V_{\mathrm{S} 1} \\
\approx 136 \mathrm{~km} / \mathrm{h}\end{array}$} & \multicolumn{2}{|c|}{$\begin{array}{c}V_{\mathrm{LE}} \\
\approx 180 \mathrm{~km} / \mathrm{h}\end{array}$} & \multicolumn{2}{|c|}{$\approx 240 \mathrm{~km} / \mathrm{h}$} & \multicolumn{2}{|c|}{$\begin{array}{c}\leq V_{\mathrm{NE}} \\
\approx 300 \mathrm{~km} / \mathrm{h}\end{array}$} \\
\hline & & left & right & left & right & left & right & left & right \\
\hline & & \multicolumn{8}{|c|}{ Impact on engine operation - crew assessment } \\
\hline \multirow{3}{*}{ Clean } & MCP & \multicolumn{2}{|c|}{$\begin{array}{l}\text { No adverse } \\
\text { impact }\end{array}$} & \multicolumn{2}{|c|}{$\begin{array}{l}\text { No adverse } \\
\text { impact }\end{array}$} & \multicolumn{2}{|c|}{$\begin{array}{l}\text { No adverse } \\
\text { impact }\end{array}$} & \multicolumn{2}{|c|}{$\begin{array}{l}\text { No adverse } \\
\text { impact }\end{array}$} \\
\hline & $\mathrm{CP}$ & \multicolumn{2}{|c|}{$\begin{array}{l}\text { No adverse } \\
\text { impact }\end{array}$} & \multicolumn{2}{|c|}{$\begin{array}{l}\text { No adverse } \\
\text { impact }\end{array}$} & \multicolumn{2}{|c|}{$\begin{array}{l}\text { No adverse } \\
\text { impact }\end{array}$} & \multicolumn{2}{|c|}{$\begin{array}{c}\text { No adverse } \\
\text { impact }\end{array}$} \\
\hline & GIP & \multicolumn{2}{|c|}{$\begin{array}{c}\text { No adverse } \\
\text { impact }\end{array}$} & \multicolumn{2}{|c|}{$\begin{array}{l}\text { No adverse } \\
\text { impact }\end{array}$} & \multicolumn{2}{|c|}{$\begin{array}{l}\text { No adverse } \\
\text { impact }\end{array}$} & \multicolumn{2}{|c|}{$\begin{array}{l}\text { No adverse } \\
\text { impact }\end{array}$} \\
\hline \multirow{3}{*}{ Landing } & MCP & \multicolumn{2}{|c|}{$\begin{array}{l}\text { No adverse } \\
\text { impact }\end{array}$} & \multicolumn{2}{|c|}{$\begin{array}{l}\text { No adverse } \\
\text { impact }\end{array}$} & & & & \\
\hline & $\mathrm{CP}$ & \multicolumn{2}{|c|}{$\begin{array}{l}\text { No adverse } \\
\text { impact }\end{array}$} & \multicolumn{2}{|c|}{$\begin{array}{c}\text { No adverse } \\
\text { impact }\end{array}$} & & & & \\
\hline & GIP & \multicolumn{2}{|c|}{$\begin{array}{c}\text { No adverse } \\
\text { impact }\end{array}$} & \multicolumn{2}{|c|}{$\begin{array}{l}\text { No adverse } \\
\text { impact }\end{array}$} & & & & \\
\hline
\end{tabular}

\subsection{Evaluation of separator impact on engine operation}

In further flight, pilots evaluated impact of the separator on the engine operation. Specific issue addressed was if the flap movement inside separator or engaged separator impairs airflow to compressor to the point where it would impact engine operation stability. The tests were again done in the same way for low and high flight altitudes (between $3700 \div 3000 \mathrm{~m}$ and $900 \div 500 \mathrm{~m}$ ) for clean configuration. Table 3 shows each task parameters and their results. The engine operated correctly in all these tests. 
Table 3. Evaluation of engine operation with the separator

\begin{tabular}{|c|c|c|c|c|c|c|c|}
\hline \multirow{4}{*}{$\begin{array}{c}\text { Airplane } \\
\text { configuration }\end{array}$} & \multirow{4}{*}{ Power } & \multicolumn{6}{|c|}{ IAS $[\mathbf{k m} / \mathbf{h}]$} \\
\hline & & \multicolumn{2}{|c|}{$\approx 1.2 \mathrm{~V}_{\mathrm{S} 1} \approx 150 \mathrm{~km} / \mathrm{h}$} & \multicolumn{2}{|c|}{$220 \mathrm{~km} / \mathrm{h}$} & \multicolumn{2}{|c|}{$\mathrm{V}_{\mathrm{NO}} \approx 290 \mathrm{~km} / \mathrm{h}$} \\
\hline & & $\begin{array}{l}\text { both way } \\
\text { selection of } \\
\text { separator }\end{array}$ & $\begin{array}{l}\text { separator } \\
\text { disengaged }\end{array}$ & $\begin{array}{l}\text { both ways } \\
\text { selection of } \\
\text { separator }\end{array}$ & $\begin{array}{c}\text { separator } \\
\text { engaged }\end{array}$ & $\begin{array}{c}\text { both ways } \\
\text { selection of } \\
\text { separator }\end{array}$ & $\begin{array}{c}\text { separator } \\
\text { engaged }\end{array}$ \\
\hline & & \multicolumn{6}{|c|}{ Impact on engine operation - crew assessment } \\
\hline \multirow{4}{*}{ Clean } & GIP & no issues & no issues & no issues & no issues & no issues & no issues \\
\hline & $\mathrm{CP}$ & no issues & no issues & no issues & no issues & no issues & no issues \\
\hline & MCP & no issues & no issues & no issues & no issues & no issues & no issues \\
\hline & TOP & no issues & no issues & no issues & no issues & no issues & no issues \\
\hline
\end{tabular}

\subsection{Engine hull vibrations evaluation}

Propeller dynamic balancing, using specialized analyzer MiroVib II, preceded in-flight engine vibration measurements. Finally, after adding proper weight, screwed to propeller hub frame, achieved dynamic imbalance was $2.13 \mathrm{~mm} / \mathrm{s}$ (vibrations acceleration was $0.48 \mathrm{~m} / \mathrm{s} 2$ at $2130 \mathrm{rpm}$ and TORQ equal to maximum continuous power), which is below that required by the propeller user flight manual, $5.02 \mathrm{~mm} / \mathrm{s}$ [8]. A flight reflecting typical normal category airplane was performed to evaluate engine hull vibrations level. The goal was to get a real engine vibrations characteristics, which can differ between engine installations. Table 4 presents the performed flight tasks.

Table 4. Flight maneuvers during engine hull vibration recording

\begin{tabular}{|l|l|c|c|}
\hline No. & \multicolumn{1}{|c|}{ Task } & $\begin{array}{c}\text { N1 } \\
{[\%]}\end{array}$ & $\begin{array}{c}\text { Timeline } \\
{[\mathbf{m i n}]}\end{array}$ \\
\hline 1. & Engine start & & 0 \\
\hline 2. & Engine warm up on the ground & & up to 4 \\
\hline 3. & Taxiing & 100 & $4 \div 5$ \\
\hline 4. & Takeoff & 100 & up to 6 \\
\hline 5. & Moving from take-off configuration to clean & $100 \rightarrow 97$ & up to 7 \\
\hline 6. & Throttling from TOP $\rightarrow$ MCP & 97 & $7 \div 17$ \\
\hline 7. & Climb to 2900 m & 97 & up to 19 \\
\hline 8. & Horizontal flight MCP & 95 & up to 21 \\
\hline 9. & Horizontal flight at CP & 95 & up to 22 \\
\hline 10. & Right turn with 50 bank at CP & 95 & \\
\hline 11. & Left turn with 50 ${ }^{\circ}$ bank at CP & 95 & up to 23 \\
\hline 12. & Right forward slip with maximum possible yaw & 95 & up to 24 \\
\hline 13. & Left forward slip with maximum possible yaw & & up to 25 \\
\hline 14. & Moving from clean to landing configuration & 46 & up to 26 \\
\hline 15. & Flight close to stall speed in landing configuration & 46 & up to 30 \\
\hline 16. & Propeller feathering & $60 \div 97$ & $30 \div 90$ \\
\hline 17. & Various maneuvers typical for normal flight & & up to 91 \\
\hline 18. & Approach & & up to 93 \\
\hline 19. & Landing & & up to 95 \\
\hline 20. & Taxiing & & 97 \\
\hline 21. & Engine shutdown & &
\end{tabular}


Fig. 3 shows recorded engine hull vibration spectrum during flight overviewed in Table 4. This spectrum is a sum of wideband noise and linear spectrum of discrete harmonic engine vibrations [9]. Acoustic noise is caused by gas generator, loose turbine, propeller, combustion chamber, air inlet, and exhaust. The main source of discrete components of engine vibrations spectrum are its blade discs. The components are result of static and dynamic imbalance of blade discs. The vibrations recording involve a flight lasting 1 hour and 37 minutes (from engine start to shutdown)

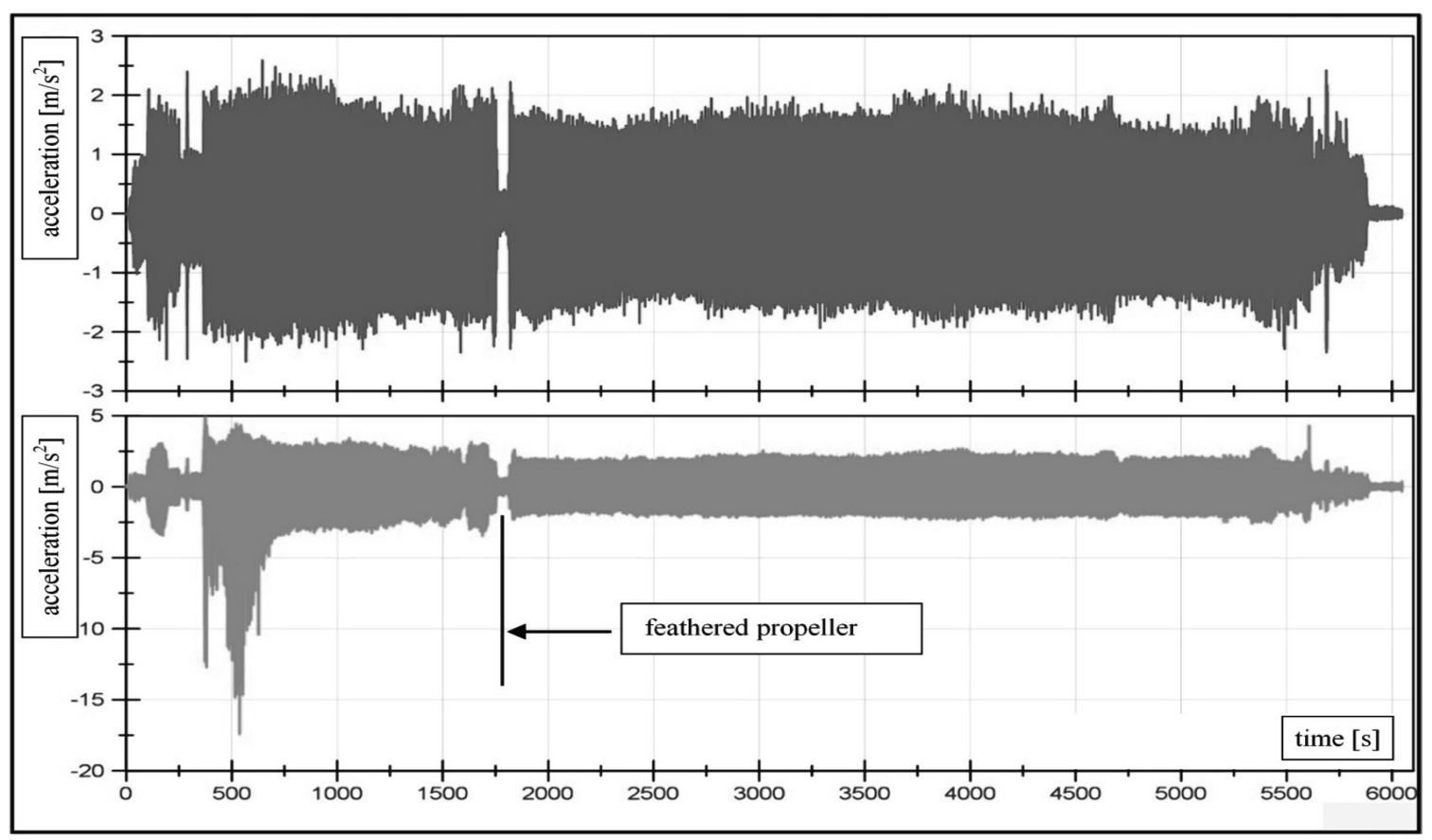

Fig. 3. Hull engine vibrations in flight (PEAK-to-PEAK values)

The upper graph in Fig. 3 shows process of radial vibrations on direction up-down (ie. in the plane perpendicular to the propeller shaft), recorded by forward sensor located at the gearbox hull in the plane of engine symmetry. The lower graph on Fig. 3 shows conduct of radial vibrations recorded by rear sensor located on the right fitting (clamp) of gas generator hull.

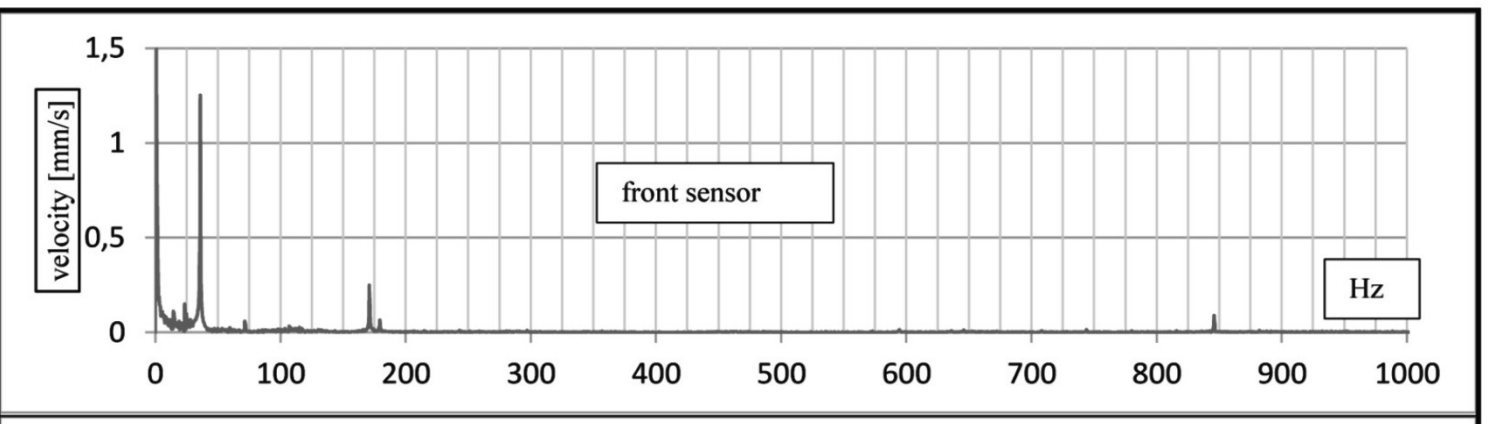




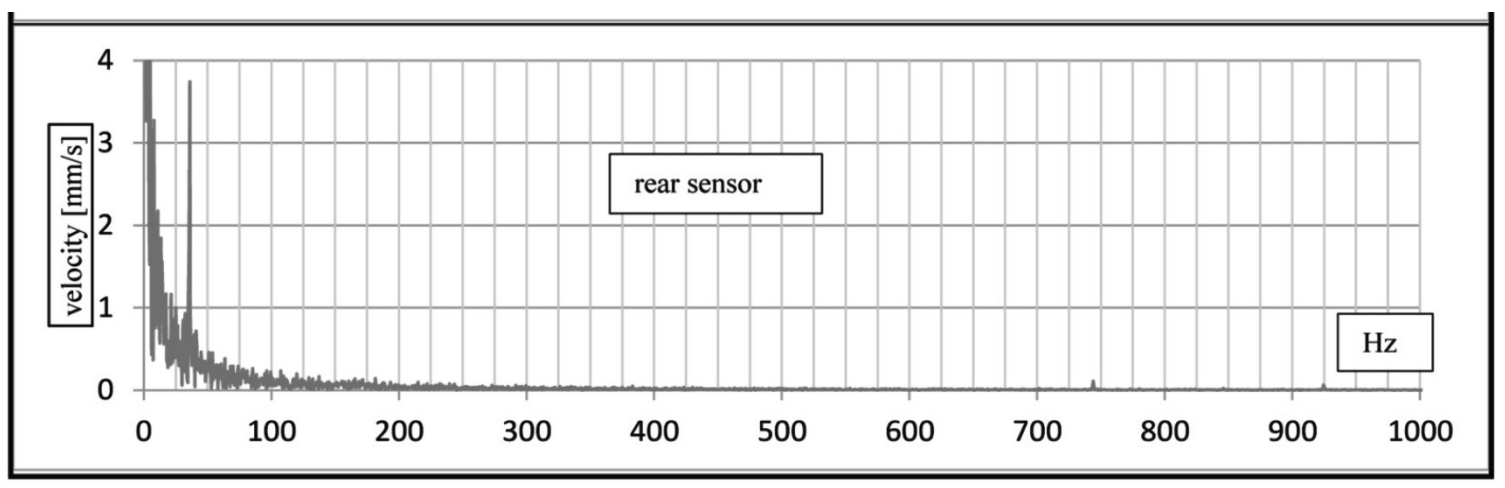

Fig. 4. Engine hull vibration spectrum

\subsection{Evaluation of engine power loss due to its installation}

A difference (loss) in power of installed vs not installed engine was evaluated by comparing brake engine performance measured after its manufacturing and in flight. The engine had worked for only 37 hours hence its wear was insignificant. Brake power characteristic power were: take-off power 179.9 $\mathrm{kW}$, maximum continuous power $159.7 \mathrm{~kW}$, cruise power $140.1 \mathrm{~kW}$. Table 5 shows flight test results. Engine parameters were recorded during two long cruise flights at two different altitudes (1000 and $3000 \mathrm{~m}$ ) with gas generator revolutions N1 $=97 / 98 \%$. The parameters were recorded with separator turned on and off.

Table 5. Parameters of flight to measure installed engine power loss

\begin{tabular}{|c|c|c|c|c|c|c|c|c|}
\hline $\begin{array}{c}\text { Altitude in } \\
\text { relations to } \\
760 \mathrm{~mm} \mathrm{Hg} \\
\text { isobaric line }[\mathrm{m}]\end{array}$ & $\begin{array}{l}\text { Separator } \\
\text { state }\end{array}$ & $\begin{array}{l}\text { OAT } \\
{\left[{ }^{\circ} \mathrm{C}\right]}\end{array}$ & $\begin{array}{c}\text { TORQ } \\
{[\%]} \\
\text { of } \\
\text { installed } \\
\text { engine }\end{array}$ & $\begin{array}{l}\text { N1 } \\
{[\%]}\end{array}$ & $\begin{array}{l}\mathbf{N 2} \\
{[\%]}\end{array}$ & $\begin{array}{c}\text { TAS } \\
{[\mathrm{km} / \mathrm{h}]}\end{array}$ & $\begin{array}{c}\text { IAS } \\
{[\mathrm{km} / \mathrm{h}]}\end{array}$ & $\begin{array}{c}\text { TORQ [\%] } \\
\text { brake power }\end{array}$ \\
\hline \multirow{2}{*}{1000} & OFF & $13 / 14$ & $87 / 88$ & $97 / 98$ & 100 & 288 & 273 & \multirow{2}{*}{89.0} \\
\hline & $\mathrm{ON}$ & 13 & $86 / 87$ & $97 / 98$ & 100 & 283 & 265 & \\
\hline \multirow{2}{*}{3000} & OFF & $6 / 5$ & $68 / 69$ & $97 / 98$ & 100 & 284 & 243 & \multirow{2}{*}{73.5} \\
\hline & ON & $6 / 5$ & 68 & $97 / 98$ & 100 & 274 & 234 & \\
\hline
\end{tabular}

Table 6 shows differences between installed engine torque $\triangle T O R Q$ and brake power $\triangle \mathrm{P}$ for selected two altitudes and for separator turned on and off. Compared brake power test values take into account temperature, referenced to the real ambient temperature referenced (OAT) at a given altitude during test flights. 
Table 6. Power difference $(\Delta \mathrm{P})$ between brake power and installed engine for two altitudes and the separator turned on and off

\begin{tabular}{|c|c|c|c|c|c|}
\hline $\begin{array}{c}\text { Altitude in } \\
\text { relations to } \\
760 \mathrm{~mm} \mathrm{Hg} \\
\text { isobaric line }[\mathrm{m}]\end{array}$ & $\begin{array}{l}\text { Separator } \\
\text { state }\end{array}$ & $\begin{array}{c}\text { TORQ [\%] } \\
\text { of installed } \\
\text { engine }\end{array}$ & $\begin{array}{c}\text { TORQ [\%] } \\
\text { brake power }\end{array}$ & $\begin{array}{c}\Delta \text { TORQ } \\
{[\%]}\end{array}$ & $\begin{array}{c}\Delta \mathbf{P} \\
{[\mathbf{k W}]}\end{array}$ \\
\hline \multirow{2}{*}{1000} & OFF & $87 / 88$ & \multirow{2}{*}{89.0} & 1.5 & 2.7 \\
\hline & $\mathrm{ON}$ & $86 / 87$ & & 2.5 & 4.3 \\
\hline \multirow{2}{*}{3000} & OFF & $68 / 69$ & \multirow{2}{*}{73.5} & 5.0 & 9.0 \\
\hline & $\mathrm{ON}$ & 68 & & 5.5 & 9.0 \\
\hline
\end{tabular}

\section{TEST RESULTS OVERVIEW}

Reverse flow air intake revers flow system with air inlet to compressor on the opposite side to the shaft applications are tractor turboprop airplanes. Cutting the weight of engine compartment can be achieved by minimizing its length, which result with a necessity of sharp curving of the duct supplying air to the compressor. This curving is a source of hydraulic losses caused by friction, flow separation or generation of induced vertices [10]. It may result with generation of a detrimental, non-uniform velocity field in front of inlet to the compressor.

The experimental flight performer confirmed good operation of the engine with the designed air duct. Airflow deformation in the inlet duct did not generate any undesired engine operation characteristics. Quality flight tests, with maneuvers such as slips, tightened turns, symmetrical pull ups and stall approaches, demonstrated satisfying engine operation characteristics in stable power range. During engine stability trials evaluating unstable power range operation with foreign objects separator, no undesired engine behavior occurred. To evaluate each undesired engine operation feature, the crew used scale with the following three levels: mild, moderate and serious severity. It is interesting to note that during the whole range of tests involving the whole normal operation envelope, the crew did not came across any hurdle concerning the engine, not even of the lowest severity. In the tested range, the engine installation design meet all the CS-23 certification requirements [2]. Differences in engine power $(\Delta \mathrm{P})$ between installed engine power and brake power, shown in Table 6, are aggregate effect of losses from engine installation, with impact of separator leakiness.

Every engine should be designed and installed in a way that no part of the engine during its operation exceeds its stress limits due to vibrations or transfer too strong forces into the airplane structure. TP100 installation manual lacks information regarding admissible hull engine vibrations in flight, as the certification had not been completed before the investigated in this article trials were completed. Practical operation of a variety of turbine engines, however, shows that such engines generate vibrations with amplitudes not exceeding $30 \div 60 \mathrm{~mm} / \mathrm{s}$ [4]. Harmonic analysis, with focus on maximum amplitudes, of recorded in flight vibrations (Table 4) show the dominant harmonic and its values for TP100 engine. Fig. 4 show resulting vibrations spectrum calculated using Fast Fourier Transform (FFT), for the point in time when the rear sensor was measuring the highest vibrations acceleration (ca. 537th second of flight). In normal conditions maximum TP100 gas generator revolutions are $56200 \mathrm{rpm}$ $(937 \mathrm{~Hz})$. Dominant component generated by the propeller $(36 \mathrm{~Hz})$ values for the rear and forward sensors are, accordingly 3.8 and $1.3 \mathrm{~mm} / \mathrm{s}$. Typical average vibration acceleration during flight reach 3.2 and $0.4 \mathrm{~mm} / \mathrm{s}$, which is much less than $30 \mathrm{~mm} / \mathrm{s}$. 
The limitation of completed fight tests is that it should have included spin test (for normal airplane category maximum two turns from entering a spin to its recovery are required), which would require time and resources consuming equipping of the aircraft prototype with emergency anti-spin system with parachute. Moreover, if the engine is equipped with air bleed valves for the airframe (TP100 does not have it), testing of its opening and closing impact would also be required.

\section{CONCLUSIONS}

Turboprop engine with revers air flow inlet system can be installed in a way that ensures proper operation of the propulsion, even if the air duct radius of curving is small. During the flight tests of the installation, no adverse engine operation characteristics, such as compressor stall, surge, flameout or excessive vibrations were ever encountered.

Ensuring leakproofness of air duct to the compressor, while the separator is turned off (not separating), is necessary so as to minimize loss of power due to its installation. Loss of power due to leaking separator may be significant.

Advantages of the proposed installation system are: simplicity of the design, low weight, good access for servicing engine components, opportunity to use various types of inlet deicing, protection against ingestion of foreign objects. These features make the proposed solution suitable for Small Aircraft Transport (SAT) Aircraft Family Program [11], as well as for redesign of small aircraft to replace piston propulsion with turboprop one [12].

\section{REFERENCES}

[1] Guła P., Iwaniuk A., 2016, "Report on validation of complex design methodology for BE1 engine integration with ACC TR1", ESPOSA Consortium Report.

[2] DECISION NO. 2003/14/RM OF THE EXECUTIVE DIRECTOR OF THE AGENCY (EASA) of 14 November 2003 on certification specifications, including airworthiness codes and acceptable means of compliance for normal, utility, aerobatic and commuter category aeroplanes (CS-23).

[3] Dudziak J., Guła P., Gawlik A., Kondracki J., 2017, "Design and manufacture of nacelles for small turboprop aircraft", Proceedings of the Institution of Mechanical Engineers, Part G: Journal of Aerospace Engineering, Volume 231, Issue 12, pp 2239-2247

[4] Goetzendorf-Grabowski T., 2014, "Formulation of the optimization problem for engine mount design - tractor propeller case", Aircraft Engineering and Aerospace Technology: An International Journal, Vol. 86 Issue: 3, pp. 228-233

[5] Idzikowski, M., Miksa, W., 2018, "Ground and In-Flight Testing of Cooling Efficiency of Turboprop Engine Compartment", TRANSACTIONS OF THE INSTITUTE OF AVIATION, No. 1(250), Warsaw, pp.16-24.

[6] Stalewski W., Żółtak J., 2014, „The preliminary design of the air-intake system and the nacelle in the small aircraft-engine integration process", Aircraft Engineering and Aerospace Technology: An International Journal, Vol. 86 Issue: 3, pp.250-258, doi: 10.1108/AEAT-01-2013-0015.

[7] Advisory Circular AC 25.939-1 - Evaluating Turbine Engine Operating Characteristics, 1986, Federal Aviation Administration.

[8] MT-propeller (E-124) „Operation and Installation Manual”, Hydraulically Controlled Variable Pitch Propeller, MTV-25-(), Issue 59, January 16, 2017. 
[9] Balicki W., Chachurski R., Głowacki P., Godzimirski J., Kawalec K., Kozakiewicz A., Pągowski Z., Rowiński A., Szczeciński J. i Szczeciński S., 2012, „Lotnicze Silniki Turbinowe, Konstrukcja - Eksploatacja - Diagnostyka, część II", Biblioteka Naukowa Instytutu Lotnictwa nr 34, Warszawa.

[10] Jeżowiecka-Kabsch K. i Szewczyk H., 2001, „Mechanika Płynów”, Oficyna Wydawnicza Politechniki Wrocławskiej, Wrocław.

[11] Piwek, K., Wiśniowski, W., 2016, "Small air transport aircraft entry requirements evoked by FlightPath 2050", Aircraft Engineering and Aerospace Technology, Vol. 88, Issue 2, pp.: 341-347.

[12] Iwaniuk, A., Wiśniowski, W. and Żółtak, J., 2016, "Multi-Disciplinary Optimisation Approach for a Light Turboprop Aircraft-Engine Integration and Improvement", Aircraft Engineering and Aerospace Technology, Vol. 88 Issue 2, pp.: 348-355.

\section{BADANIA W LOCIE SILNIKA TURBOŚMIGŁOWEGO Z UKŁADEM WLOTOWYM POWIETRZA O ODWRÓCONYM PRZEPLYWIE}

\section{Streszczenie}

Praca zawiera wybrane wyniki badań w locie zespołu napędowego samolotu I-31T, które uzyskano podczas realizacji europejskiego projektu badawczego ESPOSA (Efficient Systems and Propulsion for Small Aircraft). Samolot I-31T jako platforma badawcza był wyposażony w silnik turbośmigłowy typu TP100 o mocy startowej $180 \mathrm{~kW}$. Projekt zabudowy silnika uwzględniał wlot powietrza o odwróconym przepływie i sterowany z kabiny separator ograniczający do minimum pochłanianie przez silnik obcych ciał podczas operowania samolotu na ziemi. Omawiane próby w locie miały na celu sprawdzenie prawidłowości zasilania silnika powietrzem poprzez układ wlotowy z separatorem wyłączonym i włączonym. Przeprowadzone badania układu wlotowy wykluczyły wystąpienie niebezpiecznych charakterystyk użytkowania silnika takich jak: przeciagniecie sprężarki, pompaż czy gaśnięcie oraz potencjalne zaburzenia przepływu powietrza w układzie, mogące powodować powstawanie szkodliwych drgań korpusu silnika. Przytoczono także wyniki oceny sumarycznych strat mocy silnika związanych z jego zabudową na płatowcu.

Słowa kluczowe: samolot lekki, badania w locie, zabudowa silnika turbośmigłowego, integracja silnika turbośmigłowego, odwrócony przepływ powietrza do silnika. 